\title{
Intervention Variable in Indonesian Industry: Case Study on Capital Structure
}

\author{
Andi Kartika ${ }^{1, *}$, Cahyani Nuswandari ${ }^{2}$, Sri Sudarsi ${ }^{3}$, Ika Rosyada Fitriati ${ }^{4}$ \\ Stikubank University Semarang, Indonesia \\ andikartika@edu.unisbank.ac.id
}

\begin{abstract}
This paper examines the impact of liquidity, profitability, firm size, asset structure and capital structure on business value. From 2015 to 2018, the study's population included numerous industries listed on the Indonesia Stock Exchange. Purposive sampling was used to gather the research sample - multiple linear regression and path analysis with Partial Least Squares (PLS). Capital structure was negatively influenced by liquidity, profitability, size, and asset structure. Profitability boosts business value. Moreover, liquidity, company size, asset structure, and capital structure have no impact on firm value. The effect of liquidity, profitability, company size and asset structure on firm value is not mediated by capital structure. The obtained results show that increasing business value as measured by Price to Book Value (PBV) involves more than just financial variables and a competitive and sustainable strategy.
\end{abstract}

Keywords - Firm value, structure of capital, liquidity, profitability, firm size, structure of asset

\section{INTRODUCTION}

The growing corporate world today reflects the booming economy. This encourages organizations to operate at their best. The firm value is vital since it increases shareholder wealth. With a high price-tobook value, a company's performance in accomplishing its goals can boost shareholder wealth. Establishing a funding policy, specifically the capital structure, is one of management's initiatives to promote company value Equity and debt can be used to fund a company's activities. Capital structure, liquidity, profitability, business size and asset structure are all characteristics that have been studied in the past. A company's capital structure consists of a mix of debt and equity. The Debt to Equity Ratio measures capital structure (DER). Several earlier studies concluded that capital structure reduces corporate value [1]. Others concluded that capital structure positively impacts corporate value [2]. Capital accessible for spending and investing is liquidity - an asset to debt ratio. Liquidity enables companies to pay current bills and obligations. High corporate liquidity will help it manage current assets better, reducing the requirement for debt and lowering the DER. [3], [4], [5], [6] found a negative relationship between the current ratio and debt-equity ratio. Various studies have demonstrated that changes in a company's liquidity position have a favourable effect on debt ratios $[7,8,9,10,11]$. Liquidity has been shown to influence business value in earlier research[11] favourably. However, other studies claim that liquidity has no impact on business value [12]. Return On Assets measures the firm's profitability (ROA). Profitability can minimize debt needs.
Profitability is inversely related to DER [8]. Profit increases lower debt. Profitable companies use internal cash rather than debt $[3,4,9,13]$. In other words, organizations with adequate fund resources are less likely to be in debt [5], [14], [15]. A return on equity (ROE) measures a company's ability to repay debt. Profitability measures a company's capacity to make money from sales and investments. Profitability has been shown to positively impact business value [ 1 , $17,18]$. Various studies claim that profitability has no impact on firm value [19]. The DER is adversely affected by firm size [20]. Larger businesses have a lower proportion of debt [5], [15]. The larger the firm, the lower the percentage of debt in the capital structure [6]. Another assertion asserts that a change in the size of a business has a significant positive association with the debt ratio of the company [2], [3], and [8]. Another study discovered that large firms in Pakistan have higher leverage than smaller firms [21]. [10], the authors mentioned that firm size and debt-to-equity ratio had no discernible influence [10]. The size of the business is one of the criteria that must be considered when estimating the degree of debt that the company will incur. Firm Size is a metric that can be used to determine the size of a company (FS). Numerous prior studies indicated that firm size had a beneficial effect on firm value [1], [2], and [17]. Meanwhile, other studies suggest that the firm has little impact on the firm's worth [22]. The asset structure is one factor that affects a business's capital structure. Businesses typically finance fixed assets with capital to keep their debt minimum. Companies with a higher proportion of current assets in their asset structure tend to finance their operations through debt. In contrast, companies with a higher proportion of fixed assets finance their 
operations through equity. Asset structure has a detrimental effect on capital structure [5, [23], and [24].On the other hand, the asset structure describes the company's assets, with one of the asset structure's accounts being a fixed asset that may be used as collateral to secure loans from creditors. By and large, businesses with debt guarantees will find it simpler to obtain debt than businesses without debt collateral, implying that the asset structure has a beneficial effect on the business's debt policy [3], [7], [13], [15], [25]. According to prior studies, asset structure affects business value. Assets are the goods or property that a business owns for a specified period. The state of a business's assets might affect its financing strategy. Businesses with collateral-worthy assets will obtain loans, allowing them to access capital more quickly and thereby enhancing their company's value. The asset's structure has a beneficial effect on the firm's value [26]. This study contradicts a previous study [22], which found that asset structure has no impact on business value.

\section{HYPOTHESIS DEVELOPMENT}

\subsection{Effect of Liquidity on Capital Structure}

According to the pecking order theory, liquidity will result in a decrease in debt. Companies with a strong level of liquidity will typically cut their total deficit. As a result, liquidity has a detrimental effect on DER. According to earlier empirical research, liquidity has a damaging influence on leverage [6]. Current ratios have a detrimental impact on power [3], [4], and [5]. H1: Liquidity impairs capital structure.

\subsubsection{Profitability's Effect on} Capital Structure

According to pecking order theory, a business will prioritize its funding sources based on the idea of least effort (internal debt-equity financing), with equity financing serving as a last resort. Increased profits will result in a reduction in the company's debt ratio. Profitable businesses are more likely to employ internal money than debt [3], [4]. High-profitability companies typically have low debt levels due to their strong financial position [9], [13].

$\mathrm{H} 2$ : Profitability is detrimental to capital structure.

\subsubsection{The Capital Structure Effect of Firm Size}

The size of the business influences capital structure. The larger the company and the faster its sales growth, the more ready it will be to issue new shares and the less likely it will require debt.
Larger firms will require less external financing in debt than smaller firms [5], [15]. The debt-toequity ratio decreases with the size of the business. [6] and [20]

H3: The firm's scale has a detrimental influence on the capital structure.

\subsubsection{The Capital Structure's Effect on the Asset Structure}

The asset structure of the business affects the sources of funding. When a company has a higher proportion of tangible assets, asset assessment becomes more manageable, alleviating the information asymmetry problem. Because most businesses' capital is invested in fixed assets, they will prioritize meeting their capital demands with permanent money [23]. Capital structure has a detrimental effect on asset structure [5], [24].

H4: Capital structure has a detrimental effect on asset structure.

\subsubsection{The Liquidity Effect on Firm Value}

The ability of a business to fulfil or pay its shortterm financial obligations is referred to as liquidity. The more the liquidity, the more capable the company is of meeting its short-term obligations. The more qualified a business is of meeting its commitments, the lower the risk of liquidation it has; in other words, the less risk must be faced by the business's shareholders. This is compatible with the concept of Signaling Theory, which describes an action done by a company's management that informs investors about how the company's management views its prospects. This is corroborated by the findings of a study [11], which indicate that liquidity has a favourable effect on a firm's worth.

H5: Liquidity has a beneficial effect on a firm's value.

\subsubsection{The Profitability Effect on Firm Value}

Profitability is the end outcome of various business actions and policies. Profitability increases managers' motivation to disclose more precise information. Managers strive to persuade investors that the business is capable of achieving profitability. The greater the profitability value, the higher the stock price, which indirectly affects the company's worth. This, according to the principle of Signaling Theory, sends a clear signal to investors, encouraging them to invest in the company. The higher the stock price, the more valuable the business. Profitability is used as a proxy for the financial ratio ROA in the study. This is supported by research findings from [1], 
[2], and [17], which indicate that profitability has a considerable positive effect on business value. H6: Profitability has a beneficial effect on the value of a business.

\subsubsection{The Importance of Firm Size in Determining Firm Value}

The word "firm size" refers to the process of determining the size, dimensions, or capacity of a business to decide whether or not it is large or small. The larger the company's total assets and sales, the larger the company. The larger the asset, the greater the capital investment, whereas the more sales, the higher the company's money turnover. Larger enterprises typically operate in more stable environments, which increases their desirability to lenders seeking to improve their welfare. This steadiness will serve as a clear signal to investors, encouraging them to acquire the stock. This is corroborated by the findings of research [1], [2], [17], and [27], which indicate that firm size has a favourable effect on the firm's value.

H7: Firm size has a beneficial effect on the firm's value.

\subsubsection{The Asset Structure Effect on} Firm Value

The disposition of fixed assets determines the ultimate worth of the business. Companies with appropriate asset portfolios are more likely to seize investment opportunities as they arise. Most companies with sound financials have a high investment value in terms of fixed assets. When adequately employed by qualified personnel, they boost the return on investment for the business and, eventually, the company's value [26]. The asset structure of the business is what determines the worth of the enterprise.

H8: The asset structure of a business has a favourable effect on its value.

\subsubsection{The Capital Structure's Effect on Firm Value}

The capital structure is a financing method on a long-term basis that combines long-term debt and equity. According to agency theory, the manager (agent) is responsible for managing the company's debt. Additionally, the inability of agents to manage their debts increases the costs incurred by a business in satisfying its obligations, resulting in diminished profitability. The more the debt for the firm's operational activities, the lower the company's worth, as a high level of debt entails a heavier burden for the company. This is corroborated by the findings of a study [1], which indicate that capital structure has a detrimental effect on a firm's value.

H9: Capital structure has a detrimental effect on the firm's worth.

$$
\begin{aligned}
& \text { 2.1.9. The mediating and structure } \\
& \text { on the firm's value }
\end{aligned}
$$

Businesses with a high level of liquidity will typically cut their total debt. Increased profits will result in a decrease in the company's debt ratio. Large corporations are more likely to issue new shares and lower reliance on debt. Businesses with a high fixed asset concentration will prioritize servicing their capital requirements through permanent capital or equity. The more outstanding the debt for the company's operational activities, the lower the company's value, as the more significant the burden on the company, the smaller the proportion of debt can increase the company's value. Conversely, the smaller the ratio of debt for the company's operational activities, the greater the company's value. The capital structure acts as a buffer between liquidity, profitability, firm size, and asset structure, all of which affect business value. H10: The firm's capital structure acts as a buffer against the influence of liquidity on the firm's value.

H11: Capital structure acts as a buffer between profitability and business value.

H12: Capital structure mitigates the influence of company asset size on firm value.

H13: Capital structure acts as a buffer between the influence of asset structure on firm value and the effect of asset structure on firm value.

\section{METHODS}

\subsection{Sample}

In this section the population is the 52 businesses listed in various industries on the Indonesia Stock Exchange from 2015 to 2018. Purposive sampling is the sampling strategy used in research. While the sample criteria are as follows:

Tabel 1. Sample Selecting Procedures

\begin{tabular}{lr}
\hline \multicolumn{1}{c}{ The sample selecting Criteria } & $\begin{array}{c}\text { Sample } \\
\text { per Year }\end{array}$ \\
\hline $\begin{array}{l}\text { Miscellaneous Industry listed at Indonesia } \\
\text { Stock Exchange in } 2020\end{array}$ & 52 \\
Miscellaneous Industry not listed at Stock & \\
$\begin{array}{l}\text { Exchange of Indonesia during period of } \\
\text { 2015-2018 accordingly }\end{array}$ & \\
$\begin{array}{l}\text { Miscellaneous Industry by using foreign } \\
\text { currency in financial report }\end{array}$ & (14) \\
$\begin{array}{l}\text { Miscellaneous Industry experiencing } \\
\text { deficit during period 2015-2018 }\end{array}$ & (9) \\
Total samples used & 16 \\
\hline
\end{tabular}


observations

*total observations: $16 * 4$ years $=64$

\subsection{Analysis Technique}

The research analysis technique is multiple regression. Further it is developed into a path analysis model. The multiple regression equation can be formulated as follows:

Equation 1

Structure of capital $=\alpha 1+\beta 1$ Liquidity $+\beta 2$

Profitability $+\beta 3$ Firm Size $+\beta 3$ Asset Structure + e 1 Equation 2

$\mathrm{PBV}=\alpha 2+\beta 4 \mathrm{ROA}+\beta 5 \mathrm{CR}+\beta 6 \mathrm{SIZE}+\beta 7 \mathrm{DER}+$ e2

The limited number of research samples is the reason this study uses the Partial Least Squares (PLS) approach. The PLS approach is distribution-free [28]. The test of multicollinearity, the coefficient of determination, and the significance are used as indicators for the assessment of the goodness of fit model.

\section{RESULTS AND DISCUSSION}

\subsection{Path Analysis Results}

Path analysis was carried out using SmartPLS software, the results of which are presented in Table 2 below:

\begin{tabular}{|c|c|c|c|c|c|}
\hline & $\begin{array}{c}\text { Origin } \\
\text { al } \\
\text { Sample }\end{array}$ & $\begin{array}{c}\text { Sampl } \\
\mathrm{e} \\
\text { Mean } \\
\end{array}$ & $\begin{array}{l}\text { Standar } \\
\text { d Error }\end{array}$ & $\begin{array}{c}\mathrm{T} \\
\text { Statistic } \\
\mathrm{s} \\
\end{array}$ & $\begin{array}{c}\mathrm{P} \\
\text { Valu } \\
\mathrm{e} \\
\end{array}$ \\
\hline $\begin{array}{l}\text { Liquidity » } \\
\text { Capital } \\
\text { Structure }\end{array}$ & $-0,497$ & $-0,510$ & 0,055 & 9,088 & $\begin{array}{r}0,00 \\
0\end{array}$ \\
\hline $\begin{array}{l}\text { Profitabilit } \\
\mathrm{y} » \text { Capital } \\
\text { Structure }\end{array}$ & $-0,161$ & $-0,156$ & 0,074 & 2,169 & $\begin{array}{r}0,03 \\
1\end{array}$ \\
\hline $\begin{array}{l}\text { Firm Size } \\
\text { » Capital } \\
\text { Structure } \\
\text { Assets }\end{array}$ & $-0,244$ & $-0,250$ & 0,086 & 2,836 & $\begin{array}{r}0,00 \\
5\end{array}$ \\
\hline $\begin{array}{l}\text { Structure } \\
\gg \text { Capital } \\
\text { Structure }\end{array}$ & $-0,440$ & $-0,448$ & 0,084 & 5,216 & $\begin{array}{r}0,00 \\
0\end{array}$ \\
\hline $\begin{array}{l}\text { Liquidity » } \\
\text { Firm } \\
\text { Value }\end{array}$ & 0,063 & 0,067 & 0,090 & 0,694 & $\begin{array}{r}0,48 \\
8\end{array}$ \\
\hline $\begin{array}{l}\text { Profitabilit } \\
\text { y » Firm } \\
\text { Value }\end{array}$ & 0,765 & 0,750 & 0,093 & 8,229 & $\begin{array}{r}0,00 \\
0\end{array}$ \\
\hline $\begin{array}{l}\text { Firm Size } \\
\text { » Firm } \\
\text { Value } \\
\text { Assets }\end{array}$ & 0,144 & 0,151 & 0,084 & 1,722 & $\begin{array}{r}0,08 \\
6\end{array}$ \\
\hline $\begin{array}{l}\text { Structure } \\
\text { » Firm } \\
\text { Value }\end{array}$ & 0,065 & 0,064 & 0,096 & 0,682 & $\begin{array}{r}0,49 \\
6\end{array}$ \\
\hline $\begin{array}{l}\text { Capital } \\
\text { Structure » } \\
\text { Firm } \\
\text { Value }\end{array}$ & 0,111 & 0,112 & 0,076 & 1,466 & $\begin{array}{r}0,14 \\
3\end{array}$ \\
\hline
\end{tabular}

The regression equations that can be arranged based on Table 5 for this study are as follows:

Equation 1:

Capital Structure $\quad-0,497$ Liquidity $-0,161$

$=$

Profitability - 0,244 Firm Size 0,440 Asset Structure

Equation 2:

Firm Value $\quad 0,063$ Liquidity + 0,765 Profitability + $=\quad$ 0,144 Firm Size + 0,065 Asset

Structure + 0,111 Capital Structure

The obtained results proven that Hypothesis 1 (H1) was accepted. Liquidity harms capital structure. Companies with higher current assets tend to use less debt. This study's findings support the pecking order theory, which argues that corporations prioritize internal funds. Liquidity is observed to negatively affect capital structure in research $[3,4,5,6]$. H2 was found to be acceptable. Profitability affects the capital structure. High profitability allows organizations to employ profits as additional capital, reducing debt usage. The findings of this study support the pecking order theory, where a company's first choice for capital is internal money in the form of retained earnings. This corroborates previous findings [3, 4, 9, 13] that profitability negatively affects capital structure. H3 was accepted as a result. Firm size negatively impacts capital structure. Companies with considerable total assets can generate more profits and reinvest them more effectively. According to the pecking order principle, corporations prefer internal funding sources above external ones. This validates the findings of research $[5,6,15,20]$ that firm size affects capital structure. H4 was approved as a result. Asset structure affects capital structure. To meet their capital needs, companies with more tangible fixed assets will prioritize permanent capital, i.e. equity. This backs up research [5, 23, 24] that shows asset structure influences capital structure.

H5 was rejected. Liquidity has little impact on business value. Liquidity-rich companies can't directly increase value. The findings of this investigation defy signal theory. The company's ability to pay current obligations is insufficient to reassure investors and keep the stock price stable. According to a study [12], liquidity has little impact on firm value. H6 was approved. Profitability increases business value. Profits declared by management attract investors, increasing share price. This is signal theory. The findings of this study back up previous studies [1, 2, 17], indicating profitability boosts business value. $\mathrm{H7}$ was rejected. Firm value is unaffected by firm size. Financial stability and asset size are not helpful signals for investors and do not affect stock prices. The study's findings support [22], asserting that business size does not affect firm value. 
H8 was rejected. Asset allocation has little impact on business value. Significant fixed asset ownership does not boost firm value. This study focuses on industries that require considerable fixed assets to support operational activity. This study's findings follow research [22] that shows asset structure has little impact on firm value.

H9 was rejected in the results. The capital structure has little impact on corporate value. The company's policy for deciding the proportion of debt to equity does not affect firm value. The study's findings coincide with other studies $[22,27]$ that show capital structure has little effect on business value. The Sobel test measures capital structures' ability to mediate the effect of liquidity, profitability, company size, and asset structure on firm value. Table 7 shows the Sobel test findings.

Tabel 3. The Result of Sobel Test

\begin{tabular}{|c|c|c|c|c|c|}
\hline & A & $\mathrm{B}$ & $\mathrm{SE}_{\mathrm{A}}$ & $\mathrm{SE}_{\mathrm{B}}$ & $\mathrm{t}_{\text {statistics }}$ \\
\hline Liquidity $\quad \gg$ & & & & & \\
\hline $\begin{array}{l}\text { Structure of } \\
\text { capital » Value of } \\
\text { firm }\end{array}$ & 0,497 & 0,111 & 0,055 & 0,076 & 1,442 \\
\hline $\begin{array}{l}\text { Profitability » } \\
\text { Structure of } \\
\text { capital » Value of } \\
\text { firm }\end{array}$ & $0,161^{-}$ & 0,111 & 0,074 & 0,076 & 1,213 \\
\hline $\begin{array}{l}\text { Firm Size » } \\
\text { Structure of } \\
\text { capital » Value of } \\
\text { firm }\end{array}$ & $0,244^{-}$ & 0,111 & 0,086 & 0,076 & 1,028 \\
\hline $\begin{array}{l}\text { Assets Structure » } \\
\text { Structure of } \\
\text { capital » Value of } \\
\text { firm }\end{array}$ & $0,440^{-}$ & 0,111 & 0,084 & 0,076 & 1,407 \\
\hline
\end{tabular}

processing, 2020

The Sobel test rejects H10, 11, 12, and 13. Leverage, profitability, business size, and asset structure impact the capital structure. Capital structure is affected by liquidity, profitability, business size, and asset structure, but not firm value. Increasing organizational value requires a thorough, competitive, and sustainable strategy-

\section{CONCLUSIONAND RECOMMENDATION}

The findings indicated that liquidity, profitability, business size, and asset structure negatively impact capital structure. Profitability increases firm value, while liquidity, size, and asset structure do not. For example, in 2015-2018, the path test found that capital structure could only mediate the influence of liquidity, profitability, firm size, and asset structure. To generalize the findings to other sectors, this study's object is limited to companies listed on the Indonesian Stock Exchange in 2015. In addition to the newer or more extended observation period, researchers advise more study with additional financial and non-financial variables such as free cash flow, business risk, investment prospects, share ownership structure. It is possible to research alternative research objects, sectors or even whole sectors.

\section{REFERENCES}

[1]. Sudiyatno, B., Puspitasari, E., Suwarti, T., \& Asyif, M. M. (2020). Determinants of Firm Value and Profitability: Evidence from Indonesia. Journal of Asian Finance, Economics and Business, 7(11), 769-778. https://doi.org/10.13106/jafeb.2020.vol7.no11.769

[2]. Bandanuji, A., \& Khoiruddin, M. (2020). The Effect of Business Risk and Firm Size on Firm Value with Debt Policy as Intervening Variable. Management Analysis Journal, 9(2), 200-210. https://doi.org/10.15294/maj.v9i2.37812

[3]. Saif-Alyousfi, A. Y. H., Md-Rus, R., Taufil-Mohd, K. N., Mohd Taib, H., \& Shahar, H. K. (2020). Determinants of capital structure: evidence from Malaysian firms. Asia-Pacific Journal of Business Administration. https://doi.org/10.1108/apjba-09-2019-0202

[4]. Khémiri, W., \& Noubbigh, H. (2018). Determinants of capital structure: Evidence from sub-Saharan African firms. Quarterly Review of Economics and Finance, 70, 150-159. https://doi.org/10.1016/j.qref.2018.04.010

[5]. Alipour, M., Mohammadi, M. farhad S., \& Derakshan, H. (2015). Article information : Determinants of capital stucture : an empirical study of firms in Iran. International Journal of Law and Management, 57(1), 53-83.

[6]. Jahanzeb, A., \& Bajuri, N. H. (2014). Determinants of Capital Structure: Empirical Evidence from Pakistan. SSRN Electronic Journal, 22(2), 272-278. https://doi.org/10.2139/ssrn.1977024

[7]. Vo, X. V. (2017). Determinants of capital structure in emerging markets: Evidence from Vietnam. Research in International Business and Finance, 40, 105-113. https://doi.org/10.1016/j.ribaf.2016.12.001

[8]. Gharaibeh, A. M. O. (2015). The Determinants of Capital Structure: Empirical Evidence from Kuwait, 3(6), 1-25.

[9]. Kajananthan, R., \& Achchuthan, S. (2013). Liquidity and Capital Structure : Special reference to Sri Lanka Telecom Plc, 3(5), 89-99.

[10]. Alkhatib, K. (2012). The Determinants of Leverage of Listed Companies. International Journal of Business and Social Science, 3(24), 78-84.

[11]. Batten, J., \& Vo, X. V. (2019). Liquidity and Firm Value in an Emerging Market. Singapore Economic Review, 64(2), 365376. https://doi.org/10.1142/S0217590817470063

[12]. Sari, I. A. G. D. M., \& Sedana, I. B. P. (2020). Profitability and Liquidity on Firm Value and Capital Structure as Intervening Variable. International Research Journal of Management, IT \& Social Sciences, 7(1), 116-127. https://doi.org/10.21744/irjmis.v7n1.828

[13]. Simatupang, H. J., Purwanti, L., \& Mardiati, E. (2019). Determinants of capital structures based on the Pecking Order Theory and Trade-off Theory. Jurnal Keuangan Dan Perbankan, 23(1), 90-102. https://doi.org/10.26905/jkdp.v23i1.2579

[14]. Abdulla, Y. (2017). International Journal of Islamic and Middle Eastern Finance and Management Article information: Capital structure in a tax-free economy: evidence from UAE. International Journal of Islamic and Middle Eastern Finance and Management, 10(1).

[15]. Chadha, S., \& Sharma, A. K. (2015). Determinants of capital structure: an empirical evaluation from India. Journal of Advances in Management Research, 12(1), 3-14. https://doi.org/10.1108/JAMR-08-2014-0051

[16]. Frank, M. Z., \& Goyal, V. K. (2003). Testing the pecking order theory of capital structure. Journal of Financial Economics (Vol. 67). https://doi.org/10.1016/S0304-405X(02)00252-0 
[17]. Natsir, K., \& Yusbardini, Y. (2020). The effect of capital structure and firm size on firm value through profitability as intervening variable khairina. In Advance in Economics, Business and Management Research (Vol. 145, pp. 218-224).

[18]. Li Ju, C., \& Shun Yu, C. (2011). The Influence of Profitability on Firm Value with Capital Structure as The Mediator and Firm Size and Industry as Moderators. Investment Management and Financial Innovations, 8(3), 121-129.

[19]. Hirdinis, M. (2019). Capital structure and firm size on firm value moderated by profitability. International Journal of Economics and Business Administration, 7(1), 174-191. https://doi.org/10.35808/ijeba/204

[20]. Acaravci, S. K. (2015). The Determinants of Capital Structure: Evidence from the Turkish Manufacturing Sector. International Journal of Economics and Financial Issues, 5(1), 158-171. https://doi.org/10.1108/AJEMS-11-2012-0072

[21]. Tariq, A. (2015). The Joint-Determinants of Leverage and Dividend Policy: a Balanced Panel Study of Non Financial Firms of India, 11(10), 311-328.

[22]. S, S., \& Machali, M. (2017). The Effect of Asset Structure and Firm Size on Firm Value with Capital Structure as Intervening Variable. Journal of Business \& Financial Affairs, 06(04). https://doi.org/10.4172/2167-0234.1000298

[23]. Kawiswara, A., Hartoyo, W., Khafid, M., \& Agustina, L. (2014). Faktor-Faktor yang Mempengaruhi Struktur Modal
Perusahaan Tekstil dan Garmen Di BEI. Accounting Analysis Journal, 3(2), 247-254. https://doi.org/10.15294/aaj.v3i2.4187

[24]. Joni, \& Lina. (2010). Faktor-Faktor Yang Mempengaruhi Struktur Modal. Jurnal Bisnis Dan Akuntansi, 12(2), 82-97. https://doi.org/10.24176/agj.v4i1.4318

[25]. Sofat, R., \& Singh, S. (2017). Determinants of capital structure: an empirical study of manufacturing firms in India. International Journal of Law and Management, 59(6), 10291045. https://doi.org/10.1108/ijlma-05-2016-0051

[26]. Nyamasege, D., Okibo, W., Nyang'au, A., Sang'ania, P.O., Omosa, H., \& Momanyi, C. (2014). Effect of Asset Structure on Value of a Firm: a Case of Companies Listed In Nairobi Securities Exchange. Research Journal of Finance and Accounting, 5, 205-212.

[27]. Yusra, I., Hadya, R., Begawati, N., Istiqomah, L., Afriyeni, \& Kurniasih, N. (2019). Panel data model estimation: The effect of managerial ownership, capital structure, and company size on corporate value. Journal of Physics: Conference Series. https://doi.org/10.1088/1742-6596/1175/1/012285

[28]. Ghozali, Imam. 2014. Structural Equation Modeling Metode Alternatif Dengan Partial Least Squares (PLS). Edisi 4. Semarang: Badan Penerbit Universitas Diponegoro 